\title{
The Language of the Catcher in the Rye in the Persian Translations
}

\author{
Mostafa Sedaghat Rostami \\ Department of English Language and Literature, Kharazmi (Tarbiat Moallem) University \\ Tehran, Iran \\ E-mail: Mostafa_Sedaghat@yahoo.com
}

Received: 30-06- 2012

Accepted: 02-08- 2012

Published: 01-09- 2012

doi:10.7575/ijalel.v.1n.4p.205

URL: http://dx.doi.org/10.7575/ijalel.v.1n.4p.205

\begin{abstract}
This study aimed at investigating whether the language of the Catcher in the Rye was conveyed in its Persian translations or not. To do so, first the language of this story (i.e. the linguistic features) was described: a description of the language of this story was provided by focusing on a famous article written on the language of the Catcher in the Rye by Donald. P Costello in 1959.Of the different elements of the language of this story mentioned by Donald .P Costello, the concepts of loosely dangling phrases, grammatical elements, repetition, slangy expressions, and swear words were considered to be investigated in the Persian translations. As far as the loosely dangling phrases were concerned, 30 examples were provided from the story and compared with their Persian translation. When it came to other concepts, 15 examples were considered for the grammatical elements, 15 examples for the repetition ,15 examples for the slangy expressions, and 15 examples for the swear words. The results of the study showed that none of the translators have done perfectly in conveying the concepts mentioned above .Even though each of these linguistic features are investigated separately, 15 examples are not enough to make a conclusion concerning which translator has done a great job in conveying a special linguistic features. Because of this, a general conclusion would be made concerning the quality of the translation, considering all the 90 examples together. However, generally speaking, it can be said that the second translator, Mohammad Najafi, has done a better job compared to other translators in conveying the language of the story .It may be possible that the two other translators have done a better job compared to Mohamad Najafi in conveying the content of the story rather than its language .Finally, it can be said that similar study can be conducted in other foreign languages considering the linguistic features mentioned by Costello.
\end{abstract}

Keywords: The Catcher in the Rye, Language, Persian Translation, Costello, Translator

\section{Introduction}

J.D Salinger's famous story The Catcher in the Rye was first published in 1951.Following its publication it received a lot of praises and criticisms. Both of these critics, those praised the story and those criticized it, unanimously believed that this story could be studied not as a literary work, but as a work in which the linguistic features have a high position. In other words, this story can also be analyzed linguistically. This made the author to focus on the linguistic features of the story and to investigate whether they are conveyed appropriately in the Persian translations or not. Here it should be mentioned that to identify the linguistic features of the story, the author used a famous article on the language of The catcher in the Rye written by Donald p. Costello; this article was published in the American Speech journal in 1959.A question arises here as to why the author considered this article a reference for the identification of linguistic features of Salinger's story. The following answers can be provided to the above questions:

1. Of different articles written about The Catcher in the Rye, especially on its language, Costello's paper was mostly used as a reference work by different researchers who have carried out a research on The catcher in the Rye. Therefore, this paper was selected for the identification of the linguistic features because most scholars and researchers believed in its reliability.

2. Philosophically speaking, as mentioned by some scholars and philosophers, each reader can have different interpretation of a text in terms of content. The author believed that each person can also have a different 
interpretation of a text in terms of the language. In his article, Costello mentioned that most reviewers in different journals believed in the authenticity of the book's language (Costello himself believed in the authenticity of the book's language). However, as Costello puts it(1959:172), "Of these many reviews, only the writers for the Catholic World and the Christian Science Monitor denied the authenticity of the book's language, but both of these are religious journals which refused to believe that the 'obscenity' was realistic." Therefore, there are two groups here (those believing in the authenticity of the language and those not believing in it) and consequently there would be two kinds of readership. As far as the translation of The Catcher in the Rye is concerned, those believe in the authenticity of the language should do their best to convey the linguistic features as effectively as possible. However, those who don't believe in the authenticity of the language, may not oblige themselves to convey them ; even in some cases the translator may not have the ability to convey the linguistic features or the political powers may force the translator to ignore the linguistic features. In the case of the Persian translation of The Catcher in the Rye, the Iranian government may have forced the translator to euphemize the swear words because in the Islamic countries like Iran the norms are different from the secular countries. The author believed in the authenticity of this story's language and therefore used one of the famous articles whose writer believed in the authenticity of the language to identify the linguistic features of the story. Of different examples in which the relevant linguistic features were applied, 90 examples were selected:30 examples for the loosely dangling phrases, 15 ones for the grammatical elements, 15 ones for the repetition, 15 ones for the slangy expressions, and 15 examples for the swear words. Even though each of these linguistic features are investigated separately, 15 examples are not enough to make a conclusion concerning which translator has done a great job in conveying a special linguistic feature. Because of this, a general conclusion would be made concerning the quality of the translation considering all the 90 examples together.

As for the Persian translation of this story, there are three Persian translations of The Catcher in the Rye in the Iranian market. The first Persian translation of The Catcher in the Rye was made by Ahmad Karimi and published by cultural and scientific press in 1966( In this study, the newest edition of his translation, the eighth edition was used).Concerning this translation, it should be said that nowadays most Iranians believed Ahmad Karimi Hakak translated The Catcher in the Rye ,but it is wrong and the real translator of the first translation of The Catcher in the Rye is Ahmad Karimi, without Hakak; speaking with Ahmad Karimi Hakak, he told the author that he hasn't translated this story and the real translator is someone else: Ahmad Karimi, without Hakak. Another translation of this story was provided by Mohammad Najafi and was published by Nila Publication in 1998(As for this translation, the newest edition of it, the eighth edition was used for the analysis).In 2010, an unknown translator named Zahra Zolghadr provided a translation of this story which was published by Gostar Publication. All these three translations were investigated to come to a conclusion concerning the quality of these translations.

\section{The language of The Catcher in the Rye}

\subsection{Loosely Dangling phrases}

According to Donald .P Costello (1959: 173), "it is certainly common for teenagers to end thoughts with a loosely dangling 'and all,' just as it is common for them to add an insistent 'I really did,' 'It really was ' ". As far as The Catcher in the Rye is concerned, he mentioned the following statements concerning the loosely dangling phrases:

'Holden uses these phrases ('and all,' 'or something' and 'or anything') to such an overpowering degree that they become a clear part of the flavor of the book; they become more a part of Holden himself, and actually help to characterize him. Holden's 'and all' and its twins, 'or something,' 'or anything,' serve no real, consistent linguistic function. They simply give a sense of looseness of expression and looseness of thought. Often they signify that Holden knows there is more that could be said about the issue at hand, but he is not going to bother going into it (1959:173)." (Note 1)

Given what is mentioned above concerning the loosely dangling phrases and their function, it should be mentioned that the translators should also provide an equivalent in the target language that give a sense of looseness of expression and looseness of thought; furthermore, since , as mentioned by Costello, it is common for teenagers to end their thoughts with loosely dangling 'and all,' 'or something' and 'or anything', the translator should provide a correct equivalent to show the protagonist of the story is a teenager talking in an informal way widespread among most teenagers. The Persian translators of The Catcher in the Rye provided the following equivalents for these dangling phrases, which are completely or partially correct:

The first translator Ahmad Karimi : Va Az in Harfa, Va Ina, va inas 
International Journal of Applied Linguistics \& English Literature

ISSN 2200-3592 (Print), ISSN 2200-3452 (Online)

Vol. 1 No. 4; September 2012

The second translator Mohammad Najafi: Va az in jor chiza, va az in harfa, va az in chizast

The third translator Zahra Zolghadr: va in harfa

Generally speaking, the comparison between the selected sentences and their translation provided the following results which are classified in three tables.

Table1. Persian translations of 'and all'

\begin{tabular}{|l|c|c|c|}
\hline \multicolumn{1}{|c|}{ Translator } & Ahmad Karimi & Mohammad Najafi & Zahra Zolghadr \\
Equivalent & 3 & 9 & 1 \\
\hline Correct Equivalent & 0 & 0 & 14 \\
\hline Wrong Equivalent & 12 & 6 & 0 \\
\hline $\begin{array}{l}\text { No Equivalent } \\
\text { (Omission) }\end{array}$ & & & \\
\hline
\end{tabular}

Table one shows that none of the translators provided a wrong equivalent. However, the first translator provided 3 correct equivalents, the second translator 9 correct equivalents, and the third translator 1 correct equivalent .Furthermore, the first translator didn't provide any equivalent for twelve sentences, the second translator for six sentences, and the third translator for fourteen sentences. Therefore, it can be concluded that the out of 15 examples of the sentences ending with 'and all', the second translator was more successful compared to other translators.

Table2. Persian translations of 'Or Something'

\begin{tabular}{|l|c|c|c|}
\hline \multicolumn{1}{|c|}{ Translator } & Ahmad Karimi & Mohammad Najafi & Zolghadr \\
\hline Equivalent & 4 & 4 & 0 \\
\hline Correct Equivalent & 0 & 4 & 4 \\
\hline $\begin{array}{l}\text { No Equivalent } \\
\text { (Omission) }\end{array}$ & 4 & & 4 \\
\hline
\end{tabular}

Table 2 indicates that out of 8 sentences ending with 'or something', the three translators provided correct equivalents for 'or something' 4 times, and 4 times the element of omission was used. Therefore, all the three translators were to some extent successful in conveying the concept of 'or something' and none of them has superiority to the other in translation of this concept.

Table 3. Persian translations of 'or anything'

\begin{tabular}{|l|c|c|c|}
\hline \multicolumn{1}{|c|}{ Translator } & Ahmad Karimi & Mohammad Najafi & Zahra Zolghadr \\
\hline Equivalent & 2 & 3 & 0 \\
\hline Wrong Equivalent & 0 & 0 & 7 \\
\hline $\begin{array}{l}\text { No Equivalent } \\
\text { (Omission) }\end{array}$ & 5 & 4 & 0 \\
\hline
\end{tabular}


Table 3 shows that of these three translators in translating the seven sentences ending with 'or anything', the third translator had no success and the first and second translators were more successful compared to the third translator. Truly speaking, it should be mentioned neither the first translator nor the second one were completely successful in providing a correct equivalent for all the sentences.

Generally speaking, taking table 1, 2 and 3 into account, it is revealed that none of the translators did a great job in translating the concept of loosely dangling phrases.

\subsection{Repetition}

According to Costello (1959), Holden's choice of adjectives and adverbs is narrow with a constant repetition of a few favorite words: lousy, pretty, crumby, terrific, quite, old, stupid; in his view the repetition of a few favorite words is the habit of teenage vernacular and it has nothing to do with the meaning. Furthermore, Costello believes that limited vocabulary can be used for good comic. As he puts it, 'Holden's constant repetition of identical expressions in countless widely different situations is often hilariously funny (p.178)'.Another function of repetition (i.e. direct repetition), as mentioned by Costello, is that it serves as an evidence that Holden is conscious of his speech. Of the examples of direct repetition the following ones can be mentioned (1959:179) :

'She likes me a lot. I mean she's quite fond of me. ' (141), and 'She can be very snotty sometimes. She can be quite snotty. ' (150). Sometimes the repetition is exact: 'He was a very nervous guy-I mean he was a very nervous guy.' (165), and 'I sort of missed them. I mean I sort of missed them.' (169). Sometimes Holden stops specifically to interpret slang terms, as when he wants to communicate the fact that Allie liked Phoebe: 'She killed Allie, too. I mean he liked her, too' (64).

When it comes to the translation of the repeated words, phrases and sentences, their functions should be considered. If their function is of prime importance, as in this story the element of function serves as having a comic effect and as supporting the fact that Holden is conscious of his speech, the translator should convey the element of repetition in the translation appropriately.

To investigate how the Persian translators deal with the element of repetition, 15 examples of repetition at the sentence level were identified and then compared with their Persian translations.

Table 4. Translation of the element of repetition

\begin{tabular}{|l|c|c|c|}
\hline \multicolumn{1}{|c|}{ Translator } & Ahmad Karimi & Mohammad Najafi & Zahra Zolghadr \\
\hline Equivalent & 7 & 8 & 2 \\
\hline Wrongly conveyed & 6 & 2 & 11 \\
\hline $\begin{array}{l}\text { Not Conveyed } \\
\text { (Omission) }\end{array}$ & 2 & 5 & 2 \\
\hline
\end{tabular}

Taking table 4 into account, it can be revealed that the first translator wrongly conveyed the element of repetition 6 times, the second translator 2 times, and the third translator 2 times. The concept of wrongly conveyed in the table means that the translator just conveyed the meaning of the repeated sentence with different words rather than using the same words. In other words, the element of consistency in repetition was ignored and just conveying the meaning was the focus of attention. Generally speaking, it should be mentioned that of the three translators, the third one was the least successful. It doesn't mean that the other two translators were totally successful in dealing with the element of repetition. Truly speaking, these two translators should have done a better job in conveying the element of repetition.

\subsection{Grammatical elements}

As for the grammatical rules, Holden was self conscious, and he used wrong grammatical rules intentionally. According to Costello (1959:179), "Holden is ,in fact, not only aware of the existence of 'grammatical errors,' but knows the social taboos that accompany them." He continues that "Holden is a typical enough teenager to violate the grammar rules, even though he knows of their social importance" (1959:180). Therefore, the translator should translate in a way to show Holden violates the grammar rules. Violation of the grammar rules in 


\section{International Journal of Applied Linguistics \& English Literature}

ISSN 2200-3592 (Print), ISSN 2200-3452 (Online)

Vol. 1 No. 4; September 2012

the story and conveying it in the translations can reveal two things:

1. As Costello puts it (1959:180), "Holden is a typical enough teenager to violate the grammar rules." ; that is the protagonist of the story has his own way of speaking.

2. According to Sedaghat Rostami(2012), Holden is against the adult world where the adults believed that everything should be followed based on a rule.

When it comes to providing some examples for the grammatical errors used by Holden , the following statements have been provided by Costello(1959:180):

"His most common rule violation is the misuse of lie and lay, but he also is careless about relative pronouns ('about a traffic cop that falls in love'), the double negative ('I hardly didn't even know I was doing it'), the perfect tenses ('I'd woke him up'), extra words ('like as if all you ever did at Pency was play polo all the time'), pro-noun number ('it's pretty disgusting to watch somebody picking their nose'), and pronoun position ('I and this friend of mine, Mal Brossard')."

Of the grammatical errors mentioned by Costello, the misuse of lie and lay, the double negative, extra words were put under the investigation. Then, 15 sentences were considered: 5 sentences for the misuse of lie and lay, 5 ones for the double negative, and 5 ones for the extra word; after these sentences were identified, they were compared with their Persian translations. The following tables reveal how the Persian translators dealt with these grammatical errors included in The Catcher in the Rye.

Table 5. Misuse of lie and lay

\begin{tabular}{|l|c|c|c|}
\hline \multicolumn{1}{|c|}{ Translator } & Ahmad Karimi & Mohammad Najafi & Zahra Zolghadr \\
\hline Equivalent & 0 & 0 & 0 \\
\hline Wrong Equivalent & 0 & 0 & 5 \\
\hline $\begin{array}{l}\text { No Equivalent } \\
\text { (Omission) }\end{array}$ & 5 & 5 & 0 \\
\hline
\end{tabular}

Table 6 .Double Negative

\begin{tabular}{|l|c|c|c|}
\hline \multicolumn{1}{|c|}{ Translator } & Ahmad Karimi & Mohammad Najafi & Zahra Zolghadr \\
\hline Equivalent & 0 & 0 & 0 \\
\hline Correct Equivalent & 0 & 0 & 5 \\
\hline $\begin{array}{l}\text { No Equivalent } \\
\text { (Omission) }\end{array}$ & 5 & 5 & 0 \\
\hline
\end{tabular}

Table 7.Extra Word

\begin{tabular}{|l|c|c|c|}
\hline \multicolumn{1}{|c|}{ Translator } & Ahmad Karimi & Mohammad Najafi & Zahra Zolghadr \\
Equivalent & 0 & 0 & 0 \\
\hline Correct Equivalent & 0 & 0 & 5 \\
\hline Wrong Equivalent & 5 & 5 & 5 \\
\hline $\begin{array}{l}\text { No Equivalent } \\
\text { (Omission) }\end{array}$ & & & \\
\hline
\end{tabular}


Table 5, 6 and 7 reveal the fact that unfortunately all the three Persian translators ignored the grammatical errors of the story and therefore didn't convey the sense that Holden was a typical teenager violating the grammar rules, and that through using these grammatical errors Holden was going to show that he was against the established rules of the adult world.

\subsection{Slangy Expressions}

2.4.1 Slangy expression without precise, consistent meaning or function

Holden typically uses slang and The Catcher in the Rye is full of slangy words and expressions. In his article, Costello (1959) mentioned that in Salinger's story not all slangs had a precise and consistent meaning or function. Of these slangs that don't have precise, consistent meaning or function, Costello referred to the slang use of 'crap,' ' crazy ' and to be 'killed' by something. As far as Holden's slang use of 'crap' is concerned, Costello (1959:176) writes, "Holden's crap is used in seven different ways. It can mean foolishness, as 'all that David Copperfield kind of crap,' or messy matter, as 'I spilled some crap all over my gray flannel,' or merely miscellaneous matter, as 'I was putting on my galoshes and crap.' It can also carry its basic meaning, animal excreta, as 'there didn't look like there was anything in the park except dog crap,' and it can be used as an adjective meaning anything generally unfavorable, as 'The show was on the crappy side.' Holden uses the phrases to be a lot of crap and to shoot the crap and to chuck the crap all to mean 'to be untrue,' but he can also use to shoot the crap to mean simply 'to chat,' with no connotation of untruth, as in 'I certainly wouldn't have minded shooting the crap with old Phoebe for a while. ". Of the examples provided for the slang use of crazy, the following examples were provided by Costello: 'that drives me crazy' means that he violently dislikes something; 'to be crazy about' something means just the opposites. When it came to the description for the slangy expression of to be 'killed' by something, Costello (1959:178) wrote, "it can mean that he(Holden) was emotionally affected either favorably ('That story just about killed me.') or unfavorably ('Then she turned her back on me again. It nearly killed me.')." Therefore, taking the fact into account that the slangy expression 'to be killed by something' had both positive and negative meaning, the translators should have kept it in their mind to correctly convey its meaning; in other words, this slangy expression doesn't always have a positive meaning in Salinger's story.

To investigate how the Persian translators dealt with these slangy expression, as an example just one slangy expression (i.e. to be killed by something) which doesn't have a precise , consistent meaning or function in The Catcher in the Rye was considered, and then 15 sentences were selected randomly and were compared with their Persian translations.

Table 8.Translation of 'To be killed by something'

\begin{tabular}{|l|c|c|c|}
\hline Equivalent & Ahmad Karimi & Mohammad Najafi & Zahra Zolghadr \\
\hline Correctly conveyed & 11 & 14 & 6 \\
\hline Wrongly conveyed & 4 & 0 & 5 \\
\hline $\begin{array}{l}\text { No Equivalent } \\
\text { (Omission) }\end{array}$ & 0 & 1 & 4 \\
\hline
\end{tabular}

Table 8 shows that the second translator was more successful in translating this expression compared to other translators. The first translator provided a wrong equivalent for this slangy expression 4 times , and the third translator provided a wrong equivalent for this slangy expression 5 times. The wrongly conveyed equivalent here means that these translators provided a negative equivalent (Holden was emotionally affected unfavorably) instead of a positive equivalent (Holden was emotionally affected favorably) or vice versa.

\subsection{Swear Words}

Costello (1959) believed that the meaning of both bastard and sonuvabitch has changed drastically in Salinger's story. As he (1959: 176) puts it, "they no longer, of course, in Holden's vocabulary , have any connection with

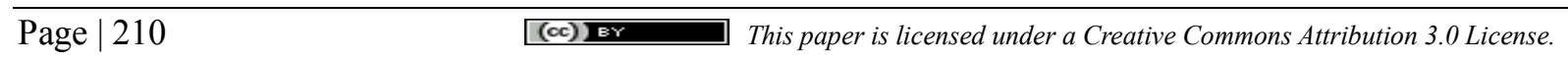


the accidents of birth. Unless used in a trite simile, bastard is a strong word, reserved for things and people Holden particularly dislikes, especially 'phonies.' Sonuvabitch has an even stronger meaning to Holden; he uses it only in the deepest anger. When, for example, Holden is furious with Stradlater over his treatment of Jane Gallagher, Holden repeats again and again that he "kept calling him a moron sonuvabitch. "When it comes to the translation of these swear words, as Sedaghat Rostami (2012) believes, the translator should be loyal to the source text and convey these swear words because they are considered the core lexis of the story. If this core lexis of the story is lost, an important aspect of the story, that is the vulgar language will be lost. Here it should be mentioned that these two swear words are not the only swear words which are used in Salinger's story; however, Costello put an emphasis on these two swear words in his article, and because of this fact, this study has focused on these two swear words; of these two swear words, sonuvabitch was selected as a representative of swear words and then 15 sentences in which this swear word was used were identified and then compared with their Persian translations. The Comparison between this swear word and its Persian translations showed that the three translators provided the following equivalents:

The first translator Ahmad Karimi : Madar Ghahbe, Fohshe Khahar va Madar

The second translator Mohammad Najafi:Chachol Baz, Olagh, Haroom Zade, Fohsh

The third translator Zahra Zolghadr: Avazi, Haram Zade,Kesafat, Ashghal

Table 9 .Translation of 'Sonuvabitch'

\begin{tabular}{|l|c|c|c|}
\hline \multicolumn{1}{|c|}{ Translator } & Ahmad Karimi & Mohammad Najafi & Zahra Zolghadr \\
\hline Equivalent & 11 & 13 & 3 \\
\hline Correct & 1 & 2 & 4 \\
\hline $\begin{array}{l}\text { No Equivalent } \\
\text { (Omission) }\end{array}$ & 3 & 0 & 8 \\
\hline
\end{tabular}

Taking the table 9 into account, it should be said, generally speaking, that the first and second translator were more successful in preserving the negativeness of this word. By the way, the first translator, to some extent maintained the rule of consistency in translating the swear word, that is he mostly stick to one correct equivalent and try not to provide synonymous words in the Persian language .Furthermore, it should be mentioned that the third translator can be the most successful translator in a society where the swear words are out of the social norms.

\section{Conclusion and Discussion}

Language plays an important role in conveying the content; the content of a text, written or spoken, can be hidden in the linguistic elements used for communication. As far as the story of The Catcher in the Rye was concerned, Salinger used intentionally some linguistic features to reveal some characteristics and clues concerning the protagonist of the story, Holden Caulfield. Taking this fact into account, the translator should not ignore these linguistic elements and convey them perfectly. If the translator doesn't achieve in conveying them, some contents of the texts will be lost in the translation. This made the author to carry out a study on how the language of The Catcher in the Rye was conveyed in its Persian translations. To do so, 90 examples were selected from the story and were compared with their Persian translations. Results of this study showed that all the three translators ignored some linguistic features; therefore, based on the 90 selected examples, none of the translators has done a great job in conveying the linguistic elements of the story in which some contents were hidden. In other words, the Persian translations of The Catcher in the Rye can't be a complete reflection of the original language of the story; there is no doubt that none of translations can be a complete representation of the original texts from which they were translated because there are different language systems preventing us from having full equivalence at different levels. Therefore, to assess a translation we should consider a continuum 
with positive and negative poles. Taking the facts that a translation can't be a complete representation of its original text, that a continuum with positive and negative poles should be considered to assess a translation, it should be said that the results of the study indicated that the Persian translations of the story are not near to the positive pole. Furthermore, a comparison between the selected sentences and their translation showed that the second translator was more successful in translating the 90 selected sentences compared to two other translators. In other words, the second translator can take the nearest place to the positive pole; the first translator can take the second nearest place and the third translator can take the third place. Finally, it should be mentioned that 90 examples are not enough to tell surely who has translated the best. This study just tried to provide a general overview of the Persian translators' effort in conveying the language of The Catcher in the Rye. Finally, it should be said that similar study can be conducted in other languages concerning the translation of The Catcher in the Rye to provide a general assessment of the translation of the story in a particular language.

\section{Acknowledgement}

The author is grateful to Dr. Ritva Leppihalme for her insightful comments on the present article.

\section{References}

Donald P. Costello (1995), The Language of The Catcher in the Rye, American Speech, Vol. 34, No. 3, pp. 172-181

Karimi, A. (2010), Natoore Dasht, $8^{\text {th }}$ vol. Tehran:Scientific and Cultural press

Najafi, M. (2010), Natoore Dasht, $8^{\text {th }}$ Vol.Tehran: Nila Press

Salinger, J. D. (1994), The Catcher in the Rye, USA: Penguin Books

Sedaghat Rostami, M. (2012),A model for the evaluation of translations: with an emphasis on the stylistic features, International Journal of Linguistics, Vol. 4,No.2:55-72

Zolghadr, Z. (2010), Natoore Dasht, $1^{\text {st }}$ Vol.Tehran:Gostar Publication

\section{Notes}

Note 1. Of the sentences ending with 'and all,' 'or something' and 'or anything', 15 sentences ending with 'and all', 8 sentences ending with 'or something' and 7 sentences ending with 'or anything' were selected and then compared with their Persian translations.

\section{Appendix}

The sentences selected from the story:

"And all"

1. ......and how my parents were occupied and all before they had me

2. They're nice and all

3. I mean that's all I told D.B. about, and he's my brother and all.

4. And I didn't know anybody there that was splendid and clear-thinking and all.

5. I was standing way the hell up on top of Thomsen Hill, right next to this crazy cannon that was in the Revolutionary War and all.

6. Anyway, it was December and all, and it was cold as a witch's teat,

7. The week before that, somebody'd stolen my camel's-hair coat right out of my Room, with my fur-lined gloves right in the pocket and all.

8. They each had their own room and all.

9. His door was open, but I sort of knocked on it anyway, just to be polite and all.

10. You never knew if he was nodding a lot because he was thinking and all, or just because he was a nice old guy that didn't know his ass from his elbow

11. What'd he say to you?"

"Oh. . well, about Life being a game and all.

12. You wouldn't think such an old guy would be so sarcastic and all. 
International Journal of Applied Linguistics \& English Literature

ISSN 2200-3592 (Print), ISSN 2200-3452 (Online)

Vol. 1 No. 4; September 2012

13."You mean about my flunking out of Pencey and all?" I said.

14. On Sundays, for instance, old Haas went around shaking hands with everybody's parents when they drove up to school. He'd be charming as hell and all.

15. "I mean it. I'll be all right. I'm just going through a phase right now. Everybody goes through phases and all, don't they?"

"or something”

1. It was the last game of the year, and you were supposed to commit suicide or something if old Pencey didn't win.

2. I like to be somewhere at least where you can see a few girls around once in a while, even if they're only scratching their arms or blowing their noses or even just giggling or something.

3. He started handling my exam paper like it was a turd or something.

4. He put my goddam paper down then and looked at me like he'd just beaten hell out of me in ping-pong or something.

5. I wondered if some guy came in a truck and took them away to a zoo or something.

6. I didn't like hearing him say that. It made me sound dead or something.

7. Then he started telling us how he was never ashamed, when he was in some kind of trouble or something, to get right down his knees and pray to God.

8. They always looked mossy and awful, and he damn near made you sick if you saw him in the dining room with his mouth full of mashed potatoes and peas or something.

"or anything”

1. Besides, I'm not going to tell you my whole goddam autobiography or anything.

2. I only had on my reversible and no gloves or anything.

3. They didn't have a maid or anything, and they always opened the door themselves.

4. "Oh. . . well, about Life being a game and all. And how you should play it according to the rules. He was pretty nice about it. I mean he didn't hit theceiling or anything. He just kept talking about Life being a game and all. You know."

5. It was a very dirty trick, but I went over and brought it over to him--I didn't have any alternative or anything.

6. "I didn't exactly flunk out or anything. I just quit, sort of."

7. Only, he's married, the cop, so be can't marry her or anything.

\section{Repetition}

1. It wasn't allowed for students to borrow faculty guys' cars, but all the athletic bastards stuck together. In every school I've gone to, all the athletic bastards stick together.

2. She once told Sally I was wild. She said I was wild and that I had no direction in life.

3. By any chance, do you happen to know where they go, the ducks, when it gets all frozen over? Do you happen to know, by any chance?"

4. She was smart even when she was a very tiny little kid. When she was a very tiny little kid, I and Allie used to take her to the park with us, especially on Sundays.

5. Then I said, "All right. What do they do, the fish and all, when that whole little lake's a solid block of ice, people skating on it and all?"Old Horwitz turned around again. "What the hellaya mean what do they do?" he yelled at me. "They stay right where they are, for Chrissake."

"They can't just ignore the ice. They can't just ignore it."

6. He had one of these very raspy voices, and he never stopped talking, practically. He never stopped talking, and what was awful was, he never said anything you wanted to hear in the first place.

7. I didn't say anything for a while. I was thinking."Supposing I went to your father and had him psychoanalyze me and all," I said. "What would he do to me? I mean what would he do to me?"

8. I kept walking and walking, and it kept getting darker and darker and spookier and spookier.

9. God, Phoebe! I can't explain. I just didn't like anything that was happening at Pencey. I can't explain." 
International Journal of Applied Linguistics \& English Literature

ISSN 2200-3592 (Print), ISSN 2200-3452 (Online)

Vol. 1 No. 4; September 2012

10. "I do! That's where you're wrong--that's exactly where you're wrong! Why the hell do you have to say that?" I said. Boy, was she depressing me.

11. It was terrible, because in the first place, he was a very nervous guy--I mean he was a very nervous guy - and his lips were always shaking whenever it was his time to make a speech, and you could hardly hear him if you were sitting way in the back of the room.

12. After a while, if I didn't see them, if they didn't come in the room, or if I didn't see them in the dining room for a couple of meals, I sort of missed them. I mean I sort of missed them."

13. It was the first time she ever told me to shut up. It sounded terrible. God, it sounded terrible. It sounded worse than swearing.

14. She killed Allie, too.I mean he liked her,too

15. The guys that are on the basketball team stick together, the Catholics stick together, the goddam intellectuals stick together, the guys that play bridge stick together.

Grammatical elements

1. Double negatives

1. Stradlater didn't say anything. That kind of stuff doesn't interest most people. "Her mother belonged to the same club we did," I said. "I used to caddy once in a while, just to make some dough. I caddy'd for her mother a couple of times. She went around in about a hundred and seventy, for nine holes."

Stradlater wasn't hardly listening. He was combing his gorgeous locks.

2. I even tried to break all the windows on the station wagon we had that summer, but my hand was already broken and everything by that time, and I couldn't do it. It was a very stupid thing to do, I'll admit, but I hardly didn't even know I was doing it, and you didn't know Allie.

3. She kept asking me if my father had a date or not. Four times she asked me that--she was certainly witty. Old Bernice, the blonde one, didn't say hardly anything at all.

4. He's a terrific snob and he won't hardly even talk to you unless you're a big shot or a celebrity or something, but he can really play the piano.

5. What made it worse, it was so quiet and lonesome out, even though it was Saturday night. I didn't see hardly anybody on the street.

Extra word

"Like as if"

1. Like as if all you ever did at Pencey was play polo all the time.

2. What he'd do was, he'd start snowing his date in this very quiet, sincere voice--like as if he wasn't only a very handsome guy but a nice, sincere guy, too.

3. And the whole three of them kept looking all around the goddam room, like as if they expected a flock of goddam movie stars to come in any minute.

4. Like as if he was a helluva humble guy, besides being a terrific piano player.

5. She came over to me, with this funny look on her face, like as if she didn't believe me.

Misuse of lie and lay

Lie, $\operatorname{lay}(p), \operatorname{Lain}(p p)$

Lay, laid (p) , laid (pp)

1. Only, instead of sitting on the arm of Stradlater's chair, he laid down on my bed, with his face right on my pillow and all.

2. I told him I was only kidding, and then I went over and laid down on Ely's bed.

3. I got up and turned it off, if it made him happy. Then I laid down on Ely's bed again.

4. So I just laid around in bed for a while and smoked another cigarette.

5. I laid awake for just a couple of seconds thinking about all that stuff Mr. Antolini'd told me. 
"To be killed by"

1. It was about this little kid that wouldn't let anybody look at his goldfish because he'd bought it with his own money. It killed me. Now he's out in Hollywood, D.B., being a prostitute.

2. Even when he was driving his car. That killed $\boldsymbol{m e}$. I just see the big phony bastard shifting into first gear and asking Jesus to send him a few more stiffs.

3. Then this girl gets killed, because she's always speeding. That story just about killed me.

4. "No, but for Chrissake, I can't just tell somebody they can sleep in his goddam bed if they want to." That killed me. I reached up from where I was sitting on the floor and patted him on the goddam shoulder.

5. "Well. He's a very sensitive boy. He's really never been a terribly good mixer with other boys. Perhaps he takes things a little more seriously than he shouldat his age." Sensitive. That killed me. That guy Morrow was about as sensitive as a goddam toilet seat.

6. She looked all around. "I don't believe this is a smoker, Rudolf," she said.Rudolf. That killed me.

7. Old Hazle Weatherfield is a girl detective. She's supposed to be an orphan, but her old man keeps showing up. Her old man's always a "tall attractive gentleman about 20 years of age." That kills me.

8. And we'd tell her who said it, and she'd say, "Oh," and go right on listening and all. She killed Allie, too. I mean he liked her, too.

9. They got all excited and asked Marty if she'd seen him and all. Old Mart said she'd only caught a glimpse of him. That killed me.

10. I mean when she was talking and she got excited about something, her mouth sort of went in about fifty directions, her lips and all. That killed me.

11. Not here." Imagine giving somebody a feel and telling them about a guy committing suicide at the same time! They killed me.

12. Then she left. The Navy guy and I told each other we were glad to've met each other. Which always kills me.

13. Calling her up night and day. Night and day--that killed me.

14. She said she had to meet her friend. Kids always have to meet their friend. That kills me.

15. He said the play itself was no masterpiece, but that the Lunts, of course, were absolute angels. Angels. For Chrissake. Angels. That killed me.

"Sonuvabitch"

1. "No reason. Boy, I can't stand that sonuvabitch.

2. He's one sonuvabitch I really can't stand."

3. Ackley said. "I don't even think the sonuvabitch is intelligent. He thinks he is. He thinks he's about the most--"

4. "I still say he's a sonuvabitch. He's a conceited sonuvabitch."

5. "Just don't do it too good, is all," he said. "That sonuvabitch Hartzell thinks you're a hot-shot in English, and he knows you're my roommate. So I mean don't stick all the commas and stuff in the right place."

6. You had to feel a little sorry for the crazy sonuvabitch.

7. He kept holding onto my wrists and I kept calling him a sonuvabitch and all, for around ten hours.

8. "You're a dirty stupid sonuvabitch of a moron," I told him.

9. But I wouldn't visit that sonuvabitch Morrow for all the dough in the world, even if I was desperate.

10. I damn near fell over on my can--he was a huge sonuvabitch.

11. But he could do one thing. The sonuvabitch could whistle better than anybody I ever heard.

12. The waiter came up, and I ordered a Coke for her--she didn't drink - and a Scotch and soda for myself, but the sonuvabitch wouldn't bring me one, so I had a Coke, too.

13. I was concealing the fact that I was a wounded sonuvabitch.

14. "No reason. Boy, I can't stand that sonuvabitch.

15. He's one sonuvabitch I really can't stand." 